Chemistry and Ecology

August 2006; Volume 22, Number 4 : 299-312

http://dx.doi.org/10.1080/02757540600812156

(c) 2006 Taylor \& Francis
Archimer http://www.ifremer.fr/docelec/ Archive Institutionnelle de l'Ifremer

The original publication is available at http://www.tandf.co.uk/journals/

\title{
Chemical contamination and sediment toxicity along the coast of Corsica
}

\author{
F.Galgani*, JF. Chiffoleau ${ }^{\circ}$, V.Orsoni ${ }^{\circ \circ}$, L. Costantini ${ }^{\circ}$, \\ P.Boissery \#, S. Calendini \#\# \& B. Andral ${ }^{\circ 0}$
}

*IFREMER, BP171, Ave. J Monnet, 34203, Sète cedex

'IFREMER, rue de l'île d'Yeu, 44311, Nantes

${ }^{\circ}$ IFREMER, zone de Furiani , 20600, Bastia

\#Agence de I eau RM \& C, La Canebiere, 13001, Marseille

\#\#Office de I Environnement de la Corse, 20250, Corte

${ }^{\circ \circ I F R E M E R, ~ z o n e ~ d e ~ B r e g a i l l o n, ~ 83507, ~ L a ~ S e y n e / m e r ~}$

*Correspondence should be addressed to F. Galgani (francois.galgani@ifremer.fr)

\begin{abstract}
:
Trace metals (Cd, Pb, Cu, Cr, Ni, Co, Zn, Hg, As, Mn, Al, Fe, and $\mathrm{Li}$ ) and organic compounds (PCBs, PAHs, lindanes, and DDT and its degradation products) were measured in coastal sediment samples from 27 sites in lagoons and along coastal areas of Corsica. An oyster embryo bioassay evaluated the toxicity of sediments from sites in three coastal lagoons (Urbino, Diane, and Biguglia) and the west coast of Cape Corsica. Despite contamination levels generally lower than those in other Mediterranean coastal areas, contamination is found in specific sites in Corsica and includes natural arsenic contamination on the east coast, insecticide pollution (persistent lindane and DDT) in many areas, both cadmium and lead contamination around Sagone, general contamination of both main harbours (Bastia and Ajaccio) and their surrounding areas, and asbestos mining residues in western Cape Corsica. Monitoring development of Crassostrea gigas embryos showed toxic effects at sites near a factory on Cape Corsica, with up to $100 \%$ mortality of larvae, and lower levels of toxicity at Sagone (44\% mortality) and in the three coastal lagoons (up to $28 \%$ mortality). Results of this regional study show the need for further monitoring to understand the environmental issues facing the Corsican coast.
\end{abstract}

Keywords: Chemical contamination, Sediment toxicity, Corsica 


\section{INTRODUCTION}

Numerous studies interpret contaminant levels in sediments as an indicator of chemical contamination of the environment [1, 2]. Coastal sediments can contain the signature of long-term contamination [3] in deep deposits as well as a more recent history of contaminant loading in the top few centimetres. Long-term monitoring programmes, however, often sample biota, including wild and caged animals, rather than sediments, to assess this contamination. Monitoring in Corsica today is limited to mussels: Levels of trace metals and organic compounds in wild mussels have been recorded since 1974 in two coastal lagoons [4] and in caged mussels around the island for the past 10 years [5]. Although sediment from specific sites has been analysed for metal [6-8] and organic [9, 10] contamination, the coastal area as a whole has not been studied. We therefore sampled and analysed sediment from 27 sites around the island to obtain insight into its chemical concentrations. We also conducted toxicity testing. Our results provide new, original and valuable information.

The coastline of Corsica is about $1000 \mathrm{~km}$ in length and includes productive ecosystems such as coastal lagoons and economically important fishing grounds as well as areas where waste products (e.g., industrial, agricultural, urban and tourist) are released. In the latter areas, sediments integrate and accumulate measurable quantities of pollutants and toxic waste. To understand the effects of these pollutants, sensitive bioassays can evaluate the spatial extent of their effects and their toxicity to marine organisms. Ghirardini [11] recently reviewed the various sediment indicators associated with toxicity to sea urchin embryos. Elsewhere, she [12] has pointed out the wide use of embryo bioassays and noted the growing interest in using indigenous species and sediment elutriates for bioassays in shallow-water areas, such as coastal lagoons, where contaminated sediment may well be resuspended. Toxicity bioassays are now used worldwide to help assess sediment quality because only responses of living systems can integrate the various complex effects of contaminants [13]. The oyster embryo bioassay, one of these procedures, has been shown to be reliable, sensitive and ecologically relevant. We chose to use this method for our study of the Corsican coastal region since native oysters live in surrounding waters. Because $C$. gigas is cultivated in the island's largest lagoons, we considered it the most suitable species for toxicity testing. The assay method has been described as a sensitive test for pesticides [14], detergents [15], antifouling paints [16] and heavy metals [17]. It has been also utilised to monitor sediment quality [18] and to measure the toxic effects of urban wastes, dredged materials and immersed cuttings [19-20] on marine organisms.

In this paper we report contaminant concentrations from 27 measuring stations along the Corsican coast and in its lagoons. We also used the $C$. gigas assay to assess sediment toxicity measured by the effects of elutriates in a study focused on Corsica's three principal coastal lagoons and sites along Cape Corsica's west coast. These results provide valuable insight in the chemical contamination of coastal sediments in Corsica. They can also serve as a scientific and technical basis for monitoring sediment quality along the Corsican coastline.

\section{MATERIALS AND METHODS}

\section{Sampling and archiving}

During three cruises on the R/V L'Europe COCON (1999, 10 sites), RINBIO (2000, 25 sites) and Canari (2001, 10 sites), coastal sediments from the top $10 \mathrm{~cm}$ were collected with a Reineck boxcorer (figure 1). Sediments were also collected with a Van Veen Grab from the Biguglia, Diane and Urbino coastal lagoons (15, 15 and 18 stations, respectively) in June 2003, after maximum river input. Subsamples from the top centimetre were then separated and stored at room temperature (for particle size determination), at $-30^{\circ} \mathrm{C}$ (for chemical analysis) or at $4{ }^{\circ} \mathrm{C}$ in the dark (in sealed bottles until hatchery-conditioned oysters were available).

Physical and chemical analyses

After preprocessing according to standardised procedures [1], laser granulometry [21] at each measuring site determined the percentage of silt particles (that is, particles with a diameter less than $63 \mu \mathrm{m})$ in the sediments sampled at sea and overall particle size distribution for the lagoon samples. After total acid digestion, lead, cadmium, copper, cobalt, chromium and nickel concentrations were determined by graphite furnace atomic absorption spectrometry and aluminium, manganese, iron, 
lithium and zinc concentrations by flame atomic absorption spectrometry [22]. Arsenic was measured by atomic fluorescence after hydride generation [23], and mercury after direct injection of dry sample in an autoanalyser [24]. Organochlorine pesticides and polychlorobiphenyls (PCBs) were extracted by dichloromethane and measured with gas-phase capillary chromatography combined with an electron capture detector. Finally, mass spectrometry was used to determine polycyclic aromatic hydrocarbons (PAHs) [25]. Results are expressed in ng or $\mu \mathrm{g}$ of contaminants per gram of dry mussel flesh.

\section{Embryo toxicity experiments}

Conditioned adult oysters (C. gigas) were induced to spawn by thermal stimulation [14] and addition of ripe gametes. These experiments used filtered natural seawater, sampled offshore. Eggs and sperm were suspended in sterile beakers and stirred for fertilisation. After 15 min fertilised eggs were counted and placed in microplate wells (IWAKI, 5 replicates per treatment) that contained $100 \mu$ l of elutriates or $100 \mu \mathrm{l}$ of whole sediment solution. Elutriates were made by adding $100 \mathrm{mg}$ sediment to $240 \mathrm{ml}$ water, agitating the mixture for $8 \mathrm{~h}$, letting it settle for $8 \mathrm{~h}$ and decanting it. Sediment solutions consisted of either 1 or $5 \mathrm{~g} \mathrm{I}^{-1}$ of freeze-dried sediment in $0.2 \mu \mathrm{m}$ filtered natural seawater. Final volumes of sediment solutions were adjusted to $300 \mu \mathrm{l}$ with natural seawater, added by micropipette. Embryos were incubated at $24 \pm 1^{\circ} \mathrm{C}$ for $24 \mathrm{~h} ; 50 \mu \mathrm{l}$ of $40 \%$ buffered formalin was then added to each vial. The percentages of abnormalities were determined according to the criteria in references 13 and 18 by direct observation of 100 randomly selected individuals per vial under an inverted microscope. Results for each site and for comparisons within samples are expressed as the net percentage of abnormalities (NPA [26], where:

NPA $=\%$ abnormal larvae - \% abnormal larvae in control

Using NPA prevents bias by the normal rate of abnormalities in the absence of sediment toxicity. Where NPA $=0$, no abnormalities related to sediment toxicity were found, whereas an NPA of 100 indicates highly toxic sediment.

Data from coastal lagoons were mapped with the kriging algorithm (50 x 50 grid) from SURFER VI (Golden Software, Golden, CO).

\section{RESULTS}

\section{Sediments}

Table 1 presents a general description of the sediment samples, listing its aluminium, manganese, iron, lithium, total organic carbon (TOC) and carbonate content as well the granulometry (percentage of silt). It shows substantial variability between the different sample sites: only 12 of 27 contained at least $30 \%$ silt. The highest value was observed at Cavu (57.4\%) and the lowest at Liscu (2.3\%). TOC also varied between measuring stations: many samples had TOC levels less than $2 \%$. These levels were highest at Sagone, Galeria and especially Bastia (up to 5.1\%), and lowest at Liscu, Porto and Tavignano (0.2\%). In all, 14 stations had more than $50 \%$ carbonates. The maximum was $90 \%$ at Portocciolo. Very few stations had less than $20 \%$ carbonates, and values were lowest at Propriano. Aluminium, lithium, iron and manganese were also heterogeneously distributed with relatively low concentrations at many stations (including lle Rousse and Bonifacio).

\section{Chemical Contamination}

Table 2 reports contaminant concentrations. Cadmium concentrations were low; the lowest levels were $0.02 \mu \mathrm{g} \mathrm{g}^{-1}$ at Calvi 3, Tavignano and Fiumor'bu, and highest at Pino, St Florent, Sagone and southern Bastia (0.14 $\mathrm{g} \mathrm{g} \mathrm{g}^{-1}$ for southern Bastia). Similarly, copper concentrations were low, except at Pino, St Florent, Cavu and, especially, southern Bastia $\left(31 \mu \mathrm{g} \mathrm{g}{ }^{-1}\right)$. Lead concentrations were highest (greater than $20 \mathrm{\mu g} \mathrm{g}^{-1}$ ) in sediments from Sagone, south and north of Ajaccio, and especially Bastia, where it reached $53.8 \mathrm{\mu g} \mathrm{g}^{-1}$. Significant mercury levels were measured only in northern Ajaccio $(0.054$ $\left.\mu \mathrm{g} \mathrm{g}^{-1}\right)$ and southern Bastia $\left(0.27 \mu \mathrm{g} \mathrm{g}^{-1}\right)$. We did not observe elevated zinc concentrations anywhere. Nickel and chromium concentrations were highest in Pino $\left(221 \mu \mathrm{g} \mathrm{g}^{-1}\right.$ and $357 \mu \mathrm{g} \mathrm{g}^{-1}$, respectively) and St Florent, while arsenic was distributed homogeneously throughout the measuring stations except in southeastern samples (up to $29 \mu \mathrm{g} \mathrm{g}^{-1}$ at Fiumalto).

Of the PCB congeners assayed, CB138 and CB157 were most common, with concentrations well above detection limits in all samples. The highest CB138 levels were found in the southern part of 
the island (Figari, Bonifaccio, Santa Amanza, Porto Vecchio and Cavu). They ranged from 1.2 to 1.6 $\mathrm{ng} \mathrm{g}^{-1}$ in Pino and northern Bastia (table 3), where DDT concentrations ranged from 1 to $4 \mathrm{ng} \mathrm{g}^{-1}$. Northern Bastia is also where the highest concentrations of DDD and DDE, DDT degradation products, were found (2.8 $\mathrm{ng} \mathrm{g}^{-1}$ and $1.9 \mathrm{ng} \mathrm{g}^{-1}$, respectively). Distribution of $\gamma \mathrm{HCH}$ (hexachlorocyclohexane) was similar to that of DDT, except in Ajaccio, where concentrations were significantly above the detection limit (0.1 ng g-1).

We analysed six PAHs, including benzo(b)fluoranthene, benzo(k)fluoranthene, benzo(a)pyrene, benzo(ghi)perylene, indeno(1,2,3-cd)pyrene and fluoranthene. All samples from every site showed similar PAH patterns. Fluoranthene and benzopyrene levels were high in two stations near Ajaccio (200 and $486 \mathrm{ng} \mathrm{g}^{-1}$, respectively) and in northern Bastia (800 and $1360 \mathrm{ng} \mathrm{g}^{-1}$, respectively).

\section{Ecotoxicology}

Toxicological tests performed with the oyster embryo bioassay and whole sediment samples showed that toxicity was not high at most of the 15 stations around the island, except in Sagone where the NPA value was $45 \%$ and, to a lesser extent, in southern Bastia, where NPA values were $12 \%$ after 24 hours.

Elutriates from sediments collected on the western side of Cape Corsica during two cruises were used to measure the effects of past asbestos mining on larval development. Samples taken in 1999 from a station located adjacent to a factory in Canari produced $100 \%$ mortality. This was confirmed in 2001 when samples from the sites near its effluent outlet were found to have 100\% mortality. Toxicity was lower farther from the Canari mining area; to the north and to the south.

We also mapped toxicity and the percentage of silt particles in the three principal coastal lagoons of Corsica, Urbino, Diane and Biguglia, where samples were taken from 18, 15 and 15 stations, respectively. Overall results indicate that their sediments are not highly toxic, with abnormal larvae values ranging from less than $10 \%$ to $28 \%$ (Diane Lagoon) (figure 3 ). Toxicity was lowest in Biguglia, where it was less than $10 \%$ in all sites, and highest in the western areas of the Urbino and Diane lagoons. There was no evidence of any relation between the percentage of silt and toxicity in sediments from any of the three coastal lagoons.

\section{DISCUSSION}

Sediments collected around Corsica vary in nature and origin. Recently, De Lazzari et al. [27 ] emphasised the importance of various factors in the distribution of individual elements or compounds in surface sediments. These include such general hydrodynamic factors as surface and deep circulation, particle size, which determines transport and dissemination through the water, mineralogical and geochemical factors and the contribution of inorganic and organic waste. The most important characteristics affecting the behavior of contaminants in surface sediments are their clay and clay silt fractions and concentrations of detrital minerals rich in organic matter, such as quartz, calcite and dolomite. Our data do not permit such an analysis. We nonetheless examined explanations for the heterogeneity in the sediments around Corsica by looking for links between contamination and the physicochemical characteristics of sediments that affect their binding to and absorption of contaminants. Sediments that are fine grained or rich in organic matter can absorb more contaminant than coarse-grained or sandy sediment. Coarse sediments, which we defined as those containing less than $30 \%$ silt, would tend to have much less affinity for contaminants than sediments containing higher percentages of finer material. Fine-grained sediments also contain more surface binding sites to immobilise particle-reactive contaminants [27] and tend to be found together with higher concentrations of organic carbon, which can absorb more contaminants, especially organic contaminants. Carbonate sediments, on the other hand, formed by the detritus of calcium-fixating benthic and planktonic organisms, generally contain lower contaminant concentrations and tend to have a diluting effect on them [28].

In our study, statistical tests of the correlation between physical parameters and contaminant levels did not demonstrate robust linear relations with either TOC or carbonates. Moreover, we could not express contaminant levels in relation to aluminium, lithium, iron or manganese because of the high variability of these cofactors. Accordingly, we interpret this chemical contamination more as a consequence of input rather than as natural concentrations or strong effects from local physical characteristics. We therefore compared the results to known sediment contaminant concentrations described in national [1] and international [28] monitoring programmes. 
Overall, contaminant levels are low in Corsica compared with those measured in the northwestern basin of the Mediterranean. This is the case for cadmium and lead, except in southern Ajaccio, southern Bastia and Sagone. It is also the case for mercury except in southern Bastia and for PCBs except for some high levels along the southern coast. Significant levels of PAHs were found in Sagone and Bastia, and sediments from the southwestern coast and Bastia contained organochlorine insecticides. Sediments from around Bastia and to a lesser extent Ajaccio contain notable levels of both metal and organic contaminants. These results cannot be explained only by the industrial activity in and around these two towns, the largest in Corsica. The high contaminant levels are more likely associated with harbour activities, including dredging and shipping, both essential activities that link the island to the continent. High TBT measurements previously reported in Corsican harbours attest to the importance of shipping and boating as a source of some of the contamination in the two harbours [10]. Widespread dredging [16] may account for most of the contamination.

Arsenic was homogeneously distributed along the eastern coast and was likely due to natural leaching of terrestrial soils and sediments [30]. Arsenic concentration increased, however, when the overall sediment content changed, as in Alistro, Solenzara and Fiumalto where samples contained low organic carbon and high $\mathrm{CaCO}_{3}$ content.

Along the southern coast, the CB138 and CB153 congeners were distributed in similar patterns. Since the measurement sites there had low levels of $\mathrm{CaCO} 3$ and relatively high concentrations of organic matter, they - especially Bonifacio - may be considered to have been polluted by PCBs. The prevalence of CB138 and CB153 at all sites demonstrated the urban origin of the initial PCBs [31], although their production has been banned for decades and a wastewater treatment plant has been in operation since 1987. The similarity of the CB138/CB153 ratio in all samples indicated the absence of specific transformation or metabolism in sediment. It also confirms the environmental persistence PCBs.

Even though lindane and DDT use stopped 30 years ago, after local eradication of malaria, these contaminants are still present - persistent and toxic. Contamination by organochlorine insecticide (and their degradation products) is still a problem, especially in Bastia and along the southern and southwest coasts, where it was found at levels significantly above the limit detection. Insecticide contamination in Corsican sediment was first described in 1994 [3], and our results indicate that more careful monitoring should continue in the years to come. The mere presence of DDTs does not indicate that they are toxic; toxicity tests are needed to make that determination. Measurement of DDT and related products is nonetheless useful for tracing chemical contamination and its long-term evolution.

Toxicity experiments clearly showed that sediments from the west coast of Cape Corsica, Sagone, and, to a lesser extent, the western parts of the Urbino and Diane lagoons had strongly toxic effects. In Biguglia, on the other hand, the sediments tested were not toxic. The two other lagoons, Urbino and Diane, receive runoff waters from agricultural areas and local river discharge (from the Arena River in the north of the Diane Lagoon). For other lagoons, the low toxicity may be explained by the lack of industry and low contaminant inputs except for the leaching of natural minerals such as arsenic. Moreover, these low toxicity levels do not increase locally when the percentage of silt in lagoons rises. We conclude from the low toxicity levels that these inputs do not have important ecological consequence.

At the Sagone stations, sediment toxicity may be related to the presence of lead and cadmium. Results in the western part of Cape Corsica and at Pino and St Florent are, however, more clearly related to the high concentration of contaminants such as chromium and nickel found in these sediments. Previous measurements found extremely high concentrations of nickel and chromium (respectively 950 and $1600 \mathrm{\mu g} \mathrm{g}^{-1}$; Chiffoleau et al, in preparation) in sediments collected around the dumping site from an old asbestos factory located on the coast near Canari. Between 1948 and 1970, 11 million tons of mechanically treated rocks and sediments were dumped at sea there. Sediment toxicity is restricted to the area around the dumping site and is related to the presence of natural components of asbestos-rich sediments such as chromium and nickel, although the organisms may also be affected by cobalt and manganese [32].

Despite the low contaminant levels compared with French [1], Spanish [33] and Italian [34] Mediterranean coastal areas as well as other islands in the northwest basin of the Mediterranean, such as the Balearic islands [33] and Sardinia [35], various specific sites are becoming contaminated in Corsica. Specific contamination includes natural arsenic on the east coast, persistent insecticides, cadmium and lead in the Sagone area, general contamination of the areas surrounding the two principal harbours, and finally the residues related to asbestos mining. Additional studies will enable us to quantify these pollutants and examine their environmental effects, geographical extent and 
evolution over time. The results of this first broad study provide a valuable baseline for further monitoring of sediment contamination in the coastal zone of Corsica.

\section{ACKNOWLEDGMENTS}

This work was partly supported by l'agence de I eau RMC and the office of environment from Corsica, both of which we thank sincerely. We also thank the captain and crew of the R/V L'Europe for logistic support, Jo Ann Cahn for editing and thank those who assisted with sampling and analysis, especially C. Ravel, G. Herve and E. His. 


\section{References}

[1] D. Claisse . Chemicals contamination of french coast : the result of a ten year mussel watch. Mar .Pollut.Bull. $20,523-528$ (1989).

[2] AM. Cicero, O. Nonnis, E. Romano, MG. Finoia, L. Bergmann, M. Graziosi, C. Balocchi, S. Focardi . Detection of tributyltin (TBT) residues in Italian marine sediments.

Chemistry and ecology , 20, Suppl 1, 319-331(2004).

[ 3]RM. Bertolotto, F. Ghioni, M. Frignani, D. Alvarado-Aguilar, LG. Bellucci, C. Cuneo, MR. Picca, E. Gollo. Polycyclic aromatic hydrocarbons in surperficial coastal sediments of the Ligurian Sea ., Mar. Poll. Bull., 46,. 7, 907-913 (2003).

[ 4] V.Orsoni, L. Constantini, C. Paoli. Resultats de la surveillance de la qualité du milieu marin , region Corse. IFREMER/RST.DEL/PAC/.O4.03 report, IFREMER editor. 73 p( 2004).

[5] B. Andral, JY. Stanisiere, E. Damier, H. Thebault, F. Galgani, P. Boissery . Monitoring chemical contamination levels in the Mediterranean based on the use of mussel caging. Mar Pollut. Bull.,49,910, 704-712, (2004).

[6] D.Claisse, D. Cossa, J., G. Touchard, B. Bombled. Methyl merccury in mussels from the french coasts. Mar. Pollut. Bull., 42, 4, 329-332 (2001).

[7]G. Pergent, C. Pergent-Martini. Mercury levels and fluxes in posidonia oceanica meadows. Environ. Pollut., 106, 1, 33-37(1999).

[ 8] JF. Chiffoleau, C. Bonneau. Chromium content in French coastal mussels and oysters. Mar Pollut. Bull., 28, 7, 458-460 (1994).

[9] D. Claisse. Surveillance du mileu marin , travaux du RNO. Les contaminants chimiques dans les sediments du littoral mediterraneen. Bulletin RNO/MAE/IFREMER, Ifremer editor, 50 p, (1998).

[10] P. Michel, B. Averty, B. Andral, JF. Chiffoleau, F. Galgani. TBT along the coasts of Corsica ( western Mediterranean : A persistant problem. Mar. Pollut. Bull., 42, 11, 1128-1132(2001).

[11] A.Volpi Ghirardini, AA. Novelli, C. Losso, PF. Ghetti . Sea urchin toxicity bioassays for sediment quality assessment in the lagoon of Venice( Italy). Chem Ecol., 19 (2-3), 99-111(2003).

[ 12] PM. Chapman, F. wang. Assessing sediment contamination in estuaries. Env. Tox. Chem., 20(1), 3-22(2002.

[13 ] AA. Novelli; C Losso; PF Ghetti \& AV Ghirardini (2003) Toxicity of heavy metals using sperm cell and embryo toxicity bioassays with paracentrotus lividus: Comparison with exposure concentrations in the laggon of Venice, Env.Tox.\& Chem, 22(6), 1295-1301.

[ 14] E.His, R. Beiras, M. Seaman. The Assessment of Marine Pollution - Bioassays with

Bivalve Embryos and Larvae. Advances in Marine Biology, volume 37, 1-178. Academic

Press, London, 178p (1999).

[ 15] C.A. Arizzi Novelli, M. Picone, D. Marchetto, G. Pessa, E. Molinaroli, PF. Ghetti, A. Volpi Ghirardini . Evaluation of superficial sediment toxicity and sediment physico-chemical characteristics of representative sites in the Lagoon of Venice (Italy). J. Mar Syst., VOL 51, 281-292 (2004).

[ 16] His E.; Heyvang I.; Geffard O. \& X. De Montaudouin(1999) A comparison between oyster (Crassostrea gigas) and sea urchin (Paracentrotus lividus) larval bioassays for toxicological studies. Water Res., 33( 7), 1706-1718.

[17] Byrne PA. \& J. O'Halloran (2001) The role of bivalve molluscs as tools in estuarine sediment toxicity testing:

a review

, Hydrobiologia , 465, 1-3, 209-217.

[18]J.E.Thain(1991) Biological effects of contaminants : oyster ( crassostrea gigas) embryo bioassay TECH. MAR. ENVIRON. SCI., 11, ICES, COPENHAGEN (DENMARK) , 12 pp.

[ 19] J. Stronkhorst, S. Ciarelli, CA. Schipper, JF. Postma, M. Dubbeldam, M. Vangheluwe, $\mathrm{JM}$. Brils, R. Hooftman. Inter-laboratory comparison of five marine bioassays for evaluating the toxicity of dredged material. Aquat. Ecosyst. Health Manage. , 7(1), 147-159 (2004)

[ 20] D. Blanchet, R. Camps, C.Dalmazzone, E. Dutrieux, J. Durrieu, E. His, P. Leminter, J. Senia, F. Galgani. Toxicity and recolonization of drill cuttings : A french experiment. Communication paper from the Society of Petroleum Engineers (SPE), San Antonio, Sept 2002, SPE editors, paper 77471, $5 \mathrm{pp}(2002)$.

[ 21] G. Billon, B. Ouddane, V. Moulin, P. Reiller. Study of the colloidal fraction in surface sediments in estuaries. J. Rech. Oceanogr., 26 (3), 168-169 (2001)

[ 22] JF. Chiffoleau, D. Auger, B. Boutier, E. Rozuel, I. Truquet . Dosage de certains métaux dans les sédiments et les matières en suspension par absorption atomique. Méthodes d'analyse en milieu marin. Ed. IFREMER, 45 p.(2003) 
[ 23] P. Michel , JF. Chiffoleau., B. Averty ., D. Auger , E.Chartier . High resolution profiles for arsenic in the Seine estuary. Seasonal variations and net fluxes to the English Channel. Continental Shelf Research, 19 : 2041-2061 (1999).

[ 24] D. Cossa , M. Coquery , K. Nakhlé , D. Claisse . Dosage du mercure et du monométhylmercure dans les organismes et les sédiments marins. Méthodes d'analyse en milieu marin. Ed. IFREMER, 26 p.(2002)

[ 25] J. Tronczyński , C. Munschy , K. Héas-Moisan , N. Guiot, I. Truquet . Analyse de contaminants organiques (PCB, OCP, HAP) dans les sédiments marins. Méthodes d'analyse en milieu marin. Ed. IFREMER, $44 \mathrm{p}$ (2005).

[ 26] R. Beiras, E. His. Effects of dissolved mercury on embryogenesis survival, growth and metamorphosis of Crassostrea gigas oyster larvae. Mar Ecol. Progress Ser. , 113, 95-103 (1994).

[ 27 ] A.De Lazzari, G.Rampazzo, B.pavoni. Geochemistry of sediments in the Northern and Central Adriatic Sea. Est. Coast. Shelf Sc., 59(3), 429-440(2004).

[ 28] JF. Chiffoleau, D. Cossa, D. Auger, I. Truquet . Trace metal distribution, partition and fluxes in the Seine estuary (France) in low discharge. Marine Chemistry 47 (1994), 145-158 (1994).

[ 29 ] C. Alzieu . Dredging and marine environment ,IFREMER Editors, Plouzané/France , 1-128 (2005).

[ 30] RNO. L'arsenic et le chrome dans les mollusques du littoral français. IFREMER/ Ministère de l'Environnement, Surveillance du milieu marin, Travaux du RNO, 1994, 25-30 ( 1994 ).

[ 31 ] T.Perez, E. Wafo, M. Fourt, J. Vacelet. Marine Sponges as Biomonitor of Polychlorobiphenyl Contamination: Concentration and Fate of 24 Congeners . Env. Sc. Technol., 37(10), 2152-2158( 2003).

[ 32] J. Schreier. Abestos fibres and associated trace metal toxicity in stream water. 11 the Annual Aquatic Toxicity Workshop. Richmond (B.C.) Nov. 13 - 15, 1984, Canada (1984).

[33] F. Ruiz . Trace metal in estuarine sediments from the southwestern spanish coast. Mar. Pollut. Bull., 42, 6, 482-490 (2001).

[34] RM. Bertolotto, F. Ghioni F, M. Frignani, D. Alvarado-Aguilar, LG. Bellucci, C. Cuneo, E. Picca, E. Gollo . Polycyclic aromatic hydrocarbons in superficial coastal sediments of the ligurian sea. Mar. Pollut. Bull., 46, 7, 907-913 (2003).

[ 35] P. Baumard, H. Budzinski, P. Garrigues. Polycyclic aromatic hydrocarbons in sediments and mussels of the Western Mediterranean Sea. Environ. Tox. \& Chem. , 17, 765-776 (1998). 


\section{CAPTIONS}

Figure 1: Sample locations for chemical analysis ( $\boldsymbol{\Delta})$ and oyster embryo bioassay $(\bullet)$ around Corsica.

Figure 2: Toxicity of sediment elutriates determined the oyster embryo bioassay in western Cape Corsica. Sediments were collected during cruises in 1999 ( A) and 2001 (B). The arrow indicates where mechanically treated sediments from an asbestos factory were dumped at sea.

Figure 3 .Toxicity of elutriates from sediments collected in Urbino, Diane and Biguglia lagoons. Data of coastal lagoon areas with toxicity (NPA) > 10\% were mapped with the kriging algorithm from Surfer VI software.

$(\bullet)$ : sampling locations.

Table 1: Description of the physicochemical characteristics of sediments collected around Corsica including the percentage of silt particles (\% particles $<63 \mu \mathrm{m}$ ), TOC (total organic carbon), carbonates $\left(\mathrm{CaCO}_{3}\right)$ and metals $\left(\mathrm{g} \mathrm{g} \mathrm{g}^{-1}\right)$ commonly used as grain-size indicators.

Table 2: Trace metal concentrations in sediments collected around Corsica. Results are expressed in $\mu \mathrm{g} \mathrm{g} \mathrm{g}^{-1}$

Table 3: PCBs concentrations in sediments collected around Corsica. Results are expressed in $\mathrm{ng} \mathrm{g}^{-1}$ for each PCB congener ( $\mathrm{CBxxx}$ )

Table 4: Polyaromatic hydrocarbons (PAHs) and organochlorine insecticides in sediments collected around Corsica. Results are expressed in $\mathrm{ng} \mathrm{g}^{-1}$

Table 5: Net percentage of abnormalities (NPA) after 24 hours of larval development of Crassostrea gigas in sediment collected around Corsica. Toxicological tests used sediment elutriate exposure procedures at various concentrations ranging from 0.1 to $5 \mathrm{~g} / \mathrm{l}$ (see materials and methods section). 
Figure 1: Sample locations for chemical analysis ( $\mathbf{\Lambda})$ and oyster embryo bioassay $(\bullet)$ around Corsica.

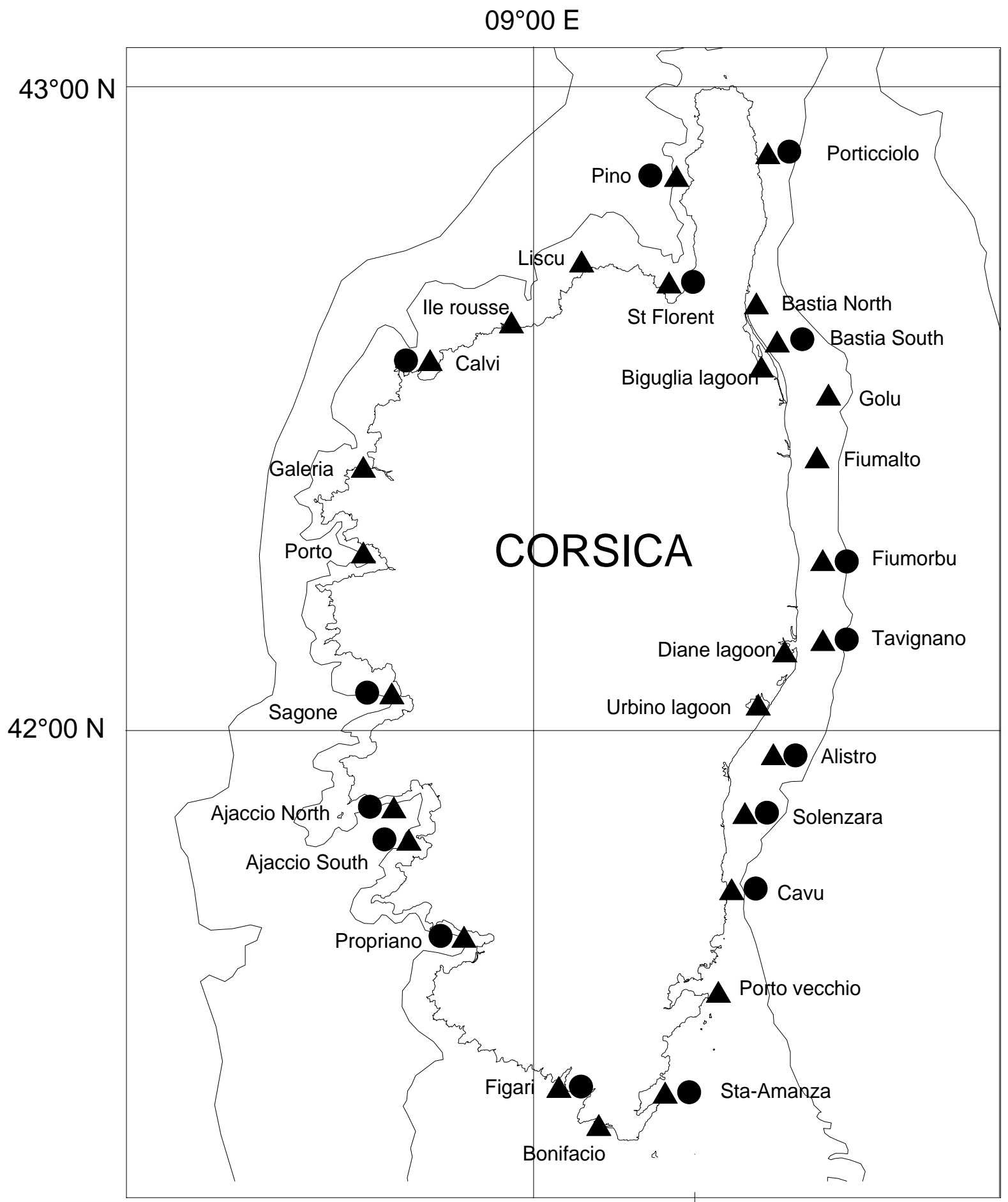


Figure 2: Toxicity of sediment elutriates determined the oyster embryo bioassay in western Cape Corsica. Sediments were collected during cruises in 1999 ( A) and 2001 (B). The arrow indicates where mechanically treated sediments from an asbestos factory were dumped at sea.
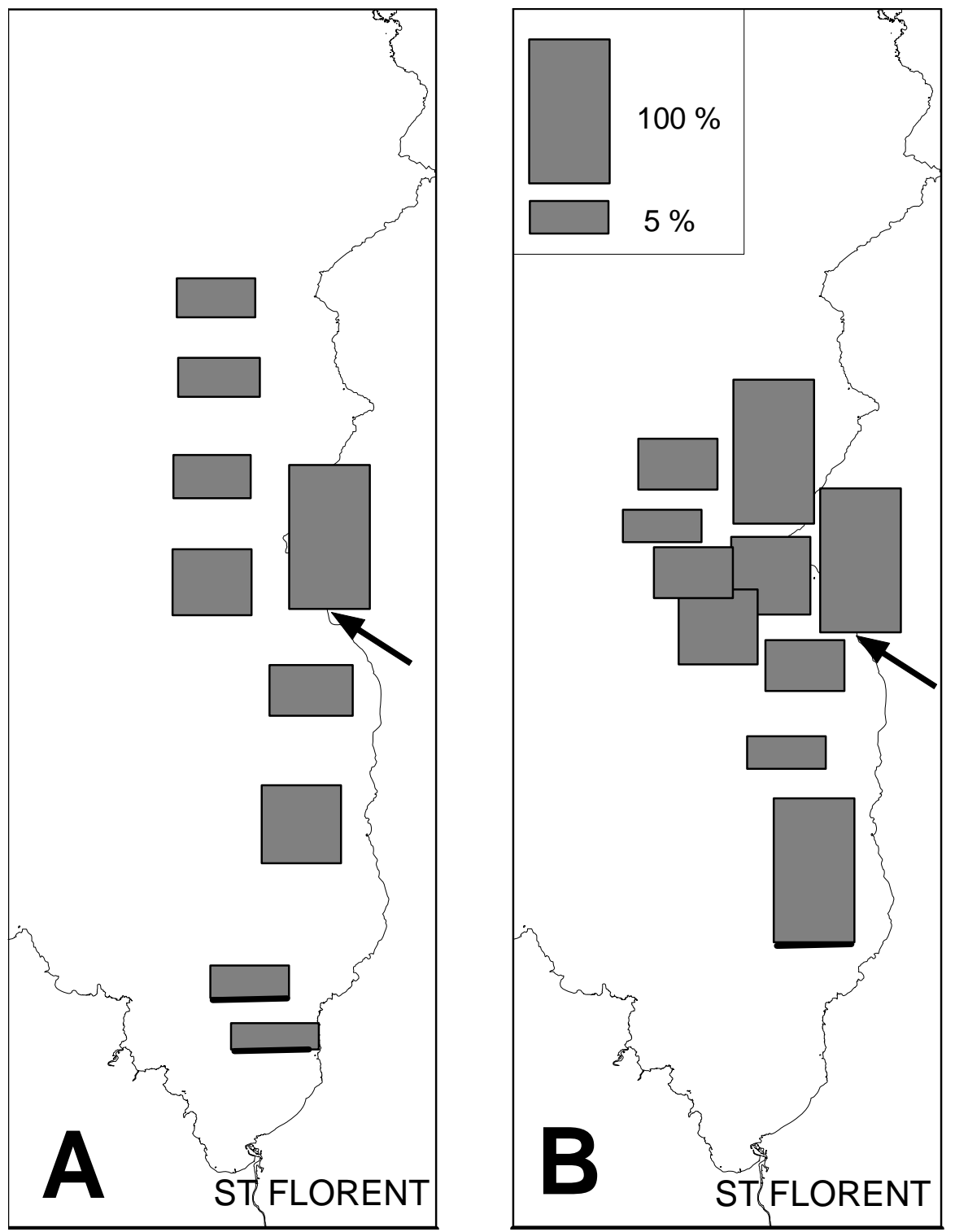
Figure 3 .Toxicity of elutriates from sediments collected in Urbino, Diane and Biguglia lagoons. Data of coastal lagoon areas with toxicity (NPA) $>10 \%$ were mapped with the kriging algorithm from Surfer VI software.

$(\bullet)$ : sampling locations.
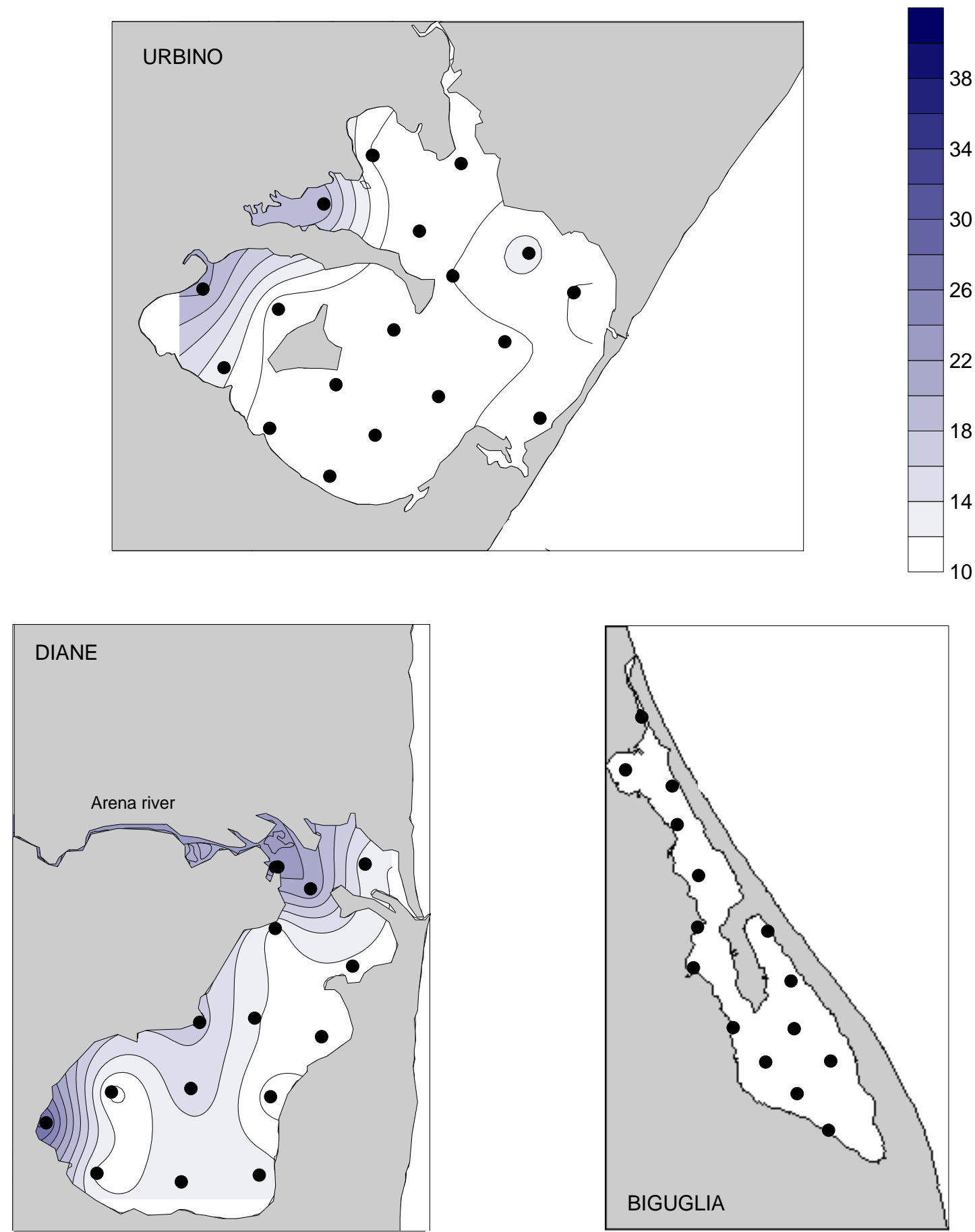
Table 1: Description of the physicochemical characteristics of sediments collected around Corsica including the percentage of silt particles $(\%$ particles < $63 \mu \mathrm{m}$ ), TOC (total organic carbon), carbonates $\left(\mathrm{CaCO}_{3}\right)$ and metals $\left(\mu \mathrm{g} \mathrm{g}^{-1}\right)$ commonly used as grain-size indicators.

\begin{tabular}{|c|c|c|c|c|c|c|c|c|c|}
\hline Station & Latitude & Longitude & $\begin{array}{c}\text { Silt } \\
(<63 \mu \mathrm{m}) \\
\%\end{array}$ & $\begin{array}{c}\mathrm{Mn} \\
\mu \mathrm{g} g-1\end{array}$ & $\begin{array}{c}\text { Al } \\
\mu g \text { g-1 }\end{array}$ & $\begin{array}{c}\text { Fe } \\
\mu \mathrm{g} g-1\end{array}$ & $\begin{array}{c}\mathrm{Li} \\
\mu \mathrm{g} g-1\end{array}$ & $\begin{array}{c}\text { TOC } \\
\%\end{array}$ & $\begin{array}{c}\mathrm{CaCO}_{3} \\
\%\end{array}$ \\
\hline Pino & $42^{\circ} 53.1$ & $09^{\circ} 17.7$ & 49.7 & 278 & 1.15 & 1.29 & 157 & 1.7 & 50.0 \\
\hline St Florent & $42^{\circ} 42.5$ & $09^{\circ} 17.2$ & 46.0 & 279 & 3.98 & 1.84 & 53 & 2.4 & 30.0 \\
\hline Liscu & $42^{\circ} 45.1$ & $09^{\circ} 10.4$ & 2.3 & 120 & 3.54 & 0.52 & 27 & 0.2 & 40.0 \\
\hline Ile Rousse & $42^{\circ} 39.2$ & $08^{\circ} 58.3$ & 6.0 & 53 & 0.97 & 0.26 & 100 & 0.6 & 88.0 \\
\hline Calvi & $42^{\circ} 34.5$ & $08^{\circ} 46.5$ & 14.1 & 106 & 5.70 & 0.83 & 45 & 0.4 & 11.0 \\
\hline Galeria & $42^{\circ} 26.1$ & $08^{\circ} 38.6$ & 16.8 & 121 & 4.01 & 0.84 & 51 & 4 & 36.0 \\
\hline Porto & $42^{\circ} 17.4$ & $08^{\circ} 39.8$ & 3.7 & 196 & 5.64 & 1.06 & 54 & 0.2 & 14.0 \\
\hline Sagone & $42^{\circ} 04.3$ & $08^{\circ} 42.5$ & 23.4 & 299 & 4.30 & 1.25 & 48 & 2.9 & 39.0 \\
\hline Ajaccio north & $41^{\circ} 54.2$ & $08^{\circ} 41.7$ & 25.0 & 196 & 2.01 & 0.70 & 43 & 2.1 & 64.0 \\
\hline Ajaccio south & $41^{\circ} 52.6$ & $08^{\circ} 45.9$ & 35.7 & 185 & 2.34 & 0.82 & 111 & 1.8 & 65.0 \\
\hline Propriano & $41^{\circ} 41.5$ & $08^{\circ} 52.1$ & 26.2 & 547 & 8.36 & 3.05 & 68 & 1.1 & 2.0 \\
\hline Figari & $41^{\circ} 26.8$ & $09^{\circ} 02.8$ & 13.9 & 108 & 1.99 & 0.33 & 41 & 0.9 & 73.0 \\
\hline Bonifaccio & $41^{\circ} 23.6$ & $09^{\circ} 07.2$ & 6.7 & 60 & 0.86 & 0.14 & 87 & 0.5 & 79.0 \\
\hline Sta Amanza & $41^{\circ} 26.7$ & $09^{\circ} 16.5$ & 45.4 & 158 & 1.64 & 0.79 & 117 & 1.4 & 68.0 \\
\hline Porto Aecchio & $41^{\circ} 36.3$ & $09^{\circ} 23.5$ & 49.5 & 224 & 2.89 & 1.26 & 138 & 0.5 & 55.0 \\
\hline Cavu & $41^{\circ} 43.9$ & $09^{\circ} 24.9$ & 57.4 & 330 & 4.23 & 1.90 & 54 & 1.6 & 38.0 \\
\hline Solenzara & $41^{\circ} 52.6$ & $09^{\circ} 26.3$ & 39.5 & 271 & 3.06 & 1.77 & 88 & 0.8 & 52.0 \\
\hline Alistro & $42^{\circ} 15.8$ & $09^{\circ} 35.4$ & 17.0 & 186 & 3.88 & 1.13 & 140 & 0.9 & 66.0 \\
\hline Tavignano & $42^{\circ} 07.6$ & $09^{\circ} 35.1$ & 14.4 & 243 & 4.83 & 1.53 & 116 & 0.2 & 19.0 \\
\hline Fiumorbu & $41^{\circ} 57.3$ & $09^{\circ} 29.4$ & 49.1 & 257 & 1.19 & 0.99 & 179 & 0.3 & 27.0 \\
\hline Fiumalto & $42^{\circ} 28.0$ & $09^{\circ} 35.4$ & 35.8 & 350 & 1.39 & 1.18 & 69 & 0.6 & 78.0 \\
\hline Golo & $42^{\circ} 32.6$ & $09^{\circ} 37.1$ & 39.9 & 217 & 1.11 & 0.76 & 52 & 0.4 & 81.0 \\
\hline Bastia south & $42^{\circ} 38.7$ & $09^{\circ} 30.1$ & 24.9 & 317 & 4.05 & 2.48 & 113 & 0.8 & 35.0 \\
\hline Bastia north & $42^{\circ} 41.4$ & $09^{\circ} 27.6$ & 33.4 & 496 & 4.95 & 3.43 & 65 & 5.1 & 10.0 \\
\hline Porticciolo & $42^{\circ} 55$ & $09^{\circ} 29.9$ & 25.9 & 138 & 0.47 & 0.56 & 128 & 1 & 90.0 \\
\hline
\end{tabular}


Table 2: Trace metal concentrations in sediments collected around Corsica. Results are expressed in $\mu \mathrm{g} \mathrm{g}^{-1}$

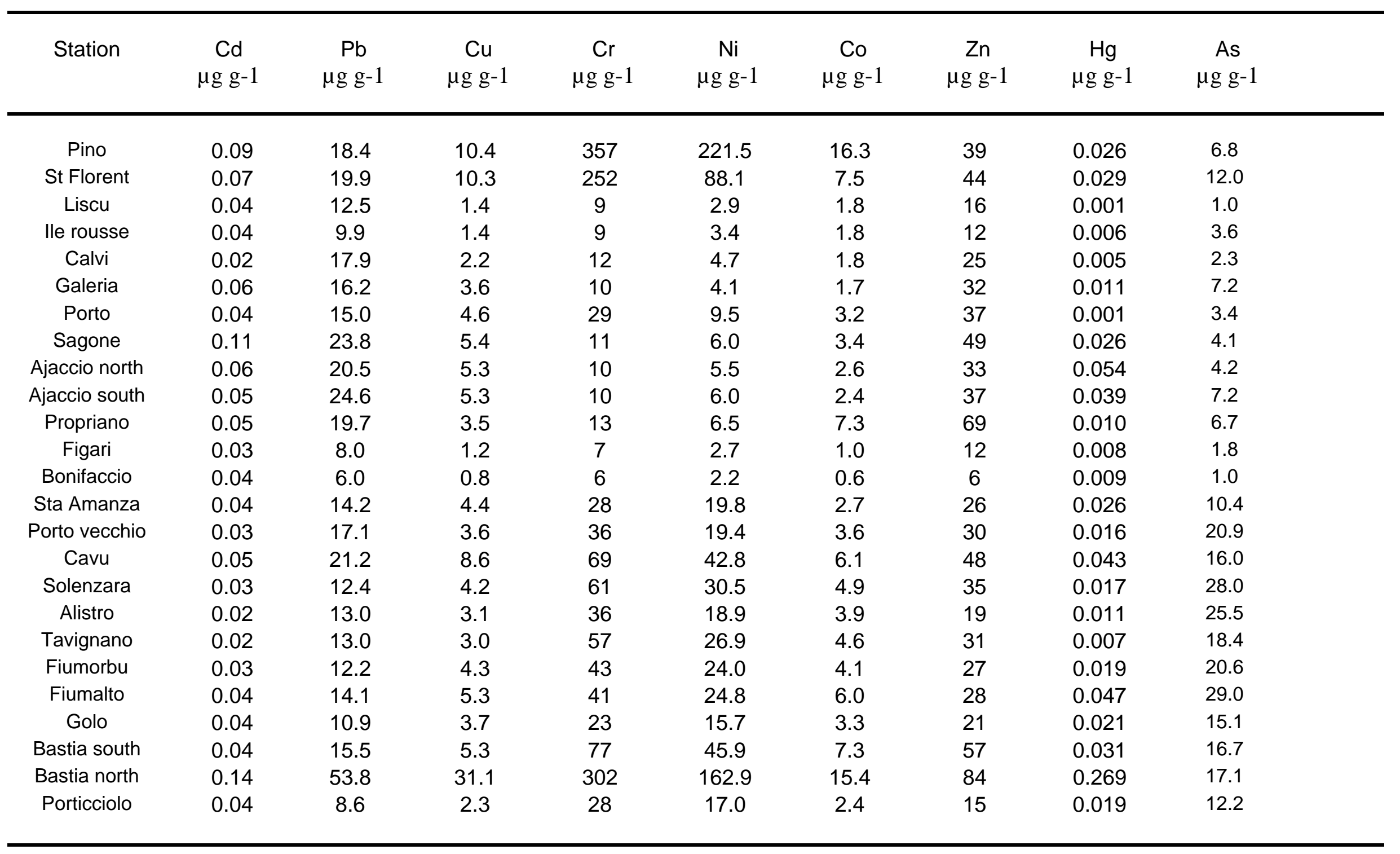


Table 3: PCBs concentrations in sediments collected around Corsica. Results are expressed in $\mathrm{ng} \mathrm{g}^{-1}$ for each PCB congener ( CBxxx)

\begin{tabular}{|c|c|c|c|c|c|c|c|c|c|c|}
\hline Station & $\begin{array}{c}\text { CB28 } \\
\text { ng g-1 }\end{array}$ & $\begin{array}{c}\text { CB31 } \\
\text { ng g-1 }\end{array}$ & $\begin{array}{l}\text { CB } 52 \\
\text { ng g-1 }\end{array}$ & $\begin{array}{l}\text { CB } 101 \\
\text { ng g-1 }\end{array}$ & $\begin{array}{l}\text { CB } 105 \\
\text { ng g-1 }\end{array}$ & $\begin{array}{l}\text { CB } 118 \\
\text { ng g-1 }\end{array}$ & $\begin{array}{l}\text { CB } 138 \\
\text { ng g-1 }\end{array}$ & $\begin{array}{l}\text { CB } 153 \\
\text { ng g-1 }\end{array}$ & $\begin{array}{l}\text { CB } 156 \\
\text { ng g-1 }\end{array}$ & $\begin{array}{c}\text { CB } 180 \\
\text { ng g-1 }\end{array}$ \\
\hline Pino & 2.210 & 1.660 & 1.280 & 2.310 & 0.910 & 2.050 & 1.550 & 1.310 & 0.210 & 0.360 \\
\hline St Florent & 0.070 & 0.020 & 0.370 & 0.310 & 0.070 & 0.320 & 0.260 & 0.220 & 0.040 & 0.060 \\
\hline Liscu & 0.360 & 0.250 & 0.090 & 0.090 & 0.010 & 0.070 & 0.050 & 0.050 & 0.010 & 0.010 \\
\hline Ile rousse & 0.100 & 0.070 & 0.120 & 0.150 & 0.010 & 0.110 & 0.080 & 0.080 & 0.010 & 0.020 \\
\hline Calvi & 0.020 & 0.020 & 0.170 & 0.170 & 0.030 & 0.150 & 0.130 & 0.110 & 0.010 & 0.030 \\
\hline Galeria & 0.370 & 0.300 & 0.680 & 0.910 & 0.030 & 0.550 & 0.410 & 0.380 & 0.010 & 0.090 \\
\hline Porto & 0.100 & 0.080 & 0.120 & 0.190 & 0.010 & 0.130 & 0.080 & 0.070 & 0.010 & 0.010 \\
\hline Sagone & 0.090 & 0.060 & 0.160 & 0.340 & 0.020 & 0.270 & 0.450 & 0.500 & 0.010 & 0.150 \\
\hline Ajaccio north & 0.060 & 0.050 & 0.220 & 0.470 & 0.030 & 0.400 & 0.480 & 0.500 & 0.020 & 0.180 \\
\hline Ajaccio south & 0.060 & 0.060 & 0.220 & 0.280 & 0.040 & 0.250 & 0.260 & 0.250 & 0.010 & 0.020 \\
\hline Propriano & 0.040 & 0.030 & 0.140 & 0.100 & 0.030 & 0.130 & 0.120 & 0.120 & 0.010 & 0.050 \\
\hline Figari & 4.120 & 3.250 & 3.260 & 4.220 & 0.770 & 1.920 & 1.210 & 1.370 & 0.150 & 0.290 \\
\hline Bonifaccio & 3.920 & 3.070 & 3.180 & 5.080 & 0.980 & 2.280 & 1.700 & 2.330 & 0.170 & 0.420 \\
\hline Sta Amanza & 4.300 & 3.290 & 3.420 & 4.660 & 0.880 & 2.030 & 1.500 & 1.770 & 0.040 & 0.400 \\
\hline Porto vecchio & 4.210 & 3.480 & 3.180 & 4.220 & 0.890 & 2.170 & 1.410 & 1.690 & 0.150 & 0.390 \\
\hline Cavu & 5.120 & 4.110 & 3.640 & 3.880 & 0.790 & 1.940 & 1.300 & 1.420 & 0.030 & 0.330 \\
\hline Solenzara & 0.040 & 0.050 & 0.170 & 0.150 & 0.010 & 0.110 & 0.080 & 0.080 & 0.005 & 0.010 \\
\hline Alistro & 0.070 & 0.060 & 0.230 & 0.360 & 0.070 & 0.330 & 0.300 & 0.240 & 0.030 & 0.040 \\
\hline Tavignano & 0.030 & 0.030 & 0.180 & 0.210 & 0.020 & 0.150 & 0.130 & 0.110 & 0.010 & 0.020 \\
\hline Fiumorbu & 0.030 & 0.020 & 0.120 & 0.130 & 0.020 & 0.050 & 0.080 & 0.080 & 0.020 & 0.020 \\
\hline Fiumalto & 2.190 & 1.680 & 1.200 & 1.570 & 0.270 & 1.130 & 0.690 & 0.660 & 0.030 & 0.190 \\
\hline Golo & 0.050 & 0.040 & 0.150 & 0.160 & 0.030 & 0.110 & 0.140 & 0.130 & 0.010 & 0.080 \\
\hline Bastia south & 1.750 & 1.360 & 1.000 & 1.260 & 0.560 & 1.930 & 0.870 & 0.830 & 0.120 & 0.300 \\
\hline Bastia north & 3.050 & 2.450 & 1.710 & 2.460 & 0.440 & 2.200 & 1.730 & 1.820 & 1.170 & 0.580 \\
\hline Porticciolo & 1.640 & 1.240 & 0.820 & 1.200 & 0.460 & 0.910 & 0.710 & 0.620 & 0.010 & 0.200 \\
\hline
\end{tabular}


Table 4: Polyaromatic hydrocarbons (PAHs) and organochlorine insecticides in sediments collected around Corsica. Results are expressed in ng $\mathrm{g}^{-1}$

\begin{tabular}{|c|c|c|c|c|c|c|c|c|c|c|c|c|c|c|}
\hline station & $\begin{array}{c}\text { Fluo } \\
\text { ng g-1 }\end{array}$ & $\begin{array}{c}\text { BenKfluo } \\
\text { ng g-1 }\end{array}$ & $\begin{array}{c}\text { BenBfluo } \\
\text { ng g-1 }\end{array}$ & $\begin{array}{c}\text { BenApyr } \\
\text { ng g-1 }\end{array}$ & $\begin{array}{l}\text { Ind123 } \\
\text { ng g-1 }\end{array}$ & $\begin{array}{c}\text { Benperyl } \\
\text { ng g-1 }\end{array}$ & $\begin{array}{l}\mathrm{AHCH} \\
\text { ng g-1 }\end{array}$ & $\begin{array}{l}\mathrm{BHCH} \\
\text { ng g-1 }\end{array}$ & $\begin{array}{l}\text { GHCH } \\
\text { ng g-1 }\end{array}$ & $\begin{array}{l}\mathrm{DHCH} \\
\text { ng g-1 }\end{array}$ & $\begin{array}{c}\text { DDE } \\
\text { ng g-1 }\end{array}$ & $\begin{array}{c}\text { DDD } \\
\text { ng g-1 }\end{array}$ & $\begin{array}{c}\text { DDT } \\
\text { ng g-1 }\end{array}$ & $\begin{array}{c}\Sigma \mathrm{DDT} \\
\text { ng g-1 }\end{array}$ \\
\hline Pino & 187 & 0.5 & 6 & 0.5 & 18 & 0.5 & 0.4 & 0.005 & 1.85 & 0.005 & 0.79 & 0.005 & 1.21 & 2.005 \\
\hline St Florent & 133 & 34 & 31 & 30 & 20 & 28 & 0.0 & 0.0 & 0.22 & 0.0 & 0.18 & 0.0 & 0.03 & 0.215 \\
\hline Liscu & 18 & 0.50 & 0.50 & 0.50 & 0.50 & 0.50 & 0.05 & 0.005 & 0.15 & 0.005 & 0.005 & 0.23 & 0.01 & 0.24 \\
\hline Ile rousse & 67 & 1 & 2 & 1 & 1 & 1 & 0.02 & 0.0 & 0.12 & 0.02 & 0.03 & 0.0 & 0.29 & 0.325 \\
\hline Calvi & 14 & 0.50 & 0.50 & 0.50 & 0.50 & 0.50 & 0.005 & 0.005 & 0.12 & 0.005 & 0.005 & 0.005 & 0.01 & 0.015 \\
\hline Galeria & 91 & 17 & 8 & 0.50 & 0.50 & 0.50 & 0.005 & 0.005 & 0.47 & 0.005 & 0.005 & 0.13 & 0.01 & 0.14 \\
\hline Porto & 30 & 0.50 & 0.50 & 0.50 & 0.50 & 0.50 & 0.005 & 0.005 & 0.27 & 0.005 & 0.005 & 0.10 & 0.01 & 0.11 \\
\hline Sagone & 0.50 & 11 & 10 & 0.50 & 0.50 & 0.50 & 0.0 & 0.0 & 0.04 & 0.0 & 0.0 & 0.04 & 0.09 & 0.135 \\
\hline Ajaccio north & 1104 & 172 & 246 & 486 & 181 & 201 & 0.0 & 0.17 & 0.16 & 0.05 & 0.57 & 1.13 & 3.82 & 5.52 \\
\hline Ajaccio south & 89 & 9 & 32 & 34 & 13 & 22 & 0.005 & 0.005 & 0.005 & 0.005 & 0.30 & 0.005 & 3.89 & 4.195 \\
\hline Propriano & 50 & 0.50 & 0.50 & 0.50 & 0.50 & 0.50 & 0.01 & 0.005 & 0.02 & 0.005 & 0.01 & 0.03 & 0.02 & 0.06 \\
\hline Figari & 14 & 0.50 & 0.50 & 0.50 & 0.50 & 0.50 & 0.23 & 0.10 & 1.97 & 0.005 & 0.60 & 1.16 & 1.14 & 2.9 \\
\hline Bonifaccio & 33 & 6 & 18 & 11 & 15 & 16 & 0.005 & 0.005 & 1.68 & 0.005 & 1.03 & 1.15 & 4.04 & 6.22 \\
\hline Sta Amanza & 20 & 0.50 & 0.50 & 0.50 & 0.50 & 0.50 & 0.29 & 0.005 & 2.4 & 0.005 & 0.99 & 1.31 & 3.32 & 5.62 \\
\hline Porto Vecchio & 72 & 0.50 & 6 & 0.50 & 0.50 & 0.50 & 0.30 & 0.07 & 2.16 & 0.04 & 0.8 & 1.31 & 3.17 & 5.28 \\
\hline Cavu & 41 & 3 & 5 & 0.50 & 0.50 & 0.50 & 0.38 & 0.005 & 2.74 & 0.005 & 0.79 & 1.70 & 2.26 & 4.75 \\
\hline Solenzara & 58 & 0.50 & 7 & 0.50 & 0.50 & 0.50 & 0.005 & 0.005 & 0.12 & 0.005 & 0.005 & 0.005 & 0.50 & 0.51 \\
\hline Alistro & 48 & 1 & 1 & 1 & 1 & 1 & 0.0 & 0.05 & 0.10 & 0.02 & 0.04 & 0.03 & 0.32 & 0.39 \\
\hline Tavignano & 63 & 1 & 1 & 1 & 1 & 1 & 0.005 & 0.005 & 0.12 & 0.005 & 0.005 & 0.005 & 0.01 & 0.015 \\
\hline Fiumorbu & 133 & 6 & 19 & 38 & 1 & 15 & 0.005 & 0.05 & 0.09 & 0.005 & 0.005 & 0.03 & 0.01 & 0.04 \\
\hline Fiumalto & 44 & 1 & 1 & 1 & 1 & 1 & 0.27 & 0.06 & 1.30 & 0.005 & 0.005 & 0.005 & 2.02 & 2.03 \\
\hline Golo & 35 & 1 & 1 & 1 & 1 & 1 & 0.005 & 0.07 & 0.04 & 0.05 & 0.04 & 0.005 & 0.13 & 0.175 \\
\hline Bastia south & 207 & 0.5 & 0.5 & 0.5 & 0.5 & 0.5 & 0.005 & 0.005 & 1.08 & 0.005 & 0.005 & 0.03 & 0.66 & 0.695 \\
\hline Bastia north & 2973 & 505 & 874 & 1361 & 768 & 787 & 0.005 & 0.005 & 1.73 & 0.005 & 1.88 & 2.77 & 0.31 & 4.96 \\
\hline Porticciolo & 143 & 0.5 & 11 & 0.5 & 0.5 & 0.5 & 0.29 & 0.005 & 1.34 & 0.005 & 0.09 & 0.04 & 2.11 & 2.24 \\
\hline
\end{tabular}


Table 5: Net percentage of abnormalities (NPA) after 24 hours of larval development of Crassostrea gigas in sediment collected around Corsica. Toxicological tests used sediment elutriate exposure procedures at various concentrations ranging from 0.1 to $5 \mathrm{~g} / \mathrm{l}$ (see materials and methods section).

\begin{tabular}{cccccccc}
\hline Station & Lat(N) & Long(E) & $0.1 \mathrm{~g} / \mathrm{l}$ & $0,5 \mathrm{~g} / \mathrm{l}$ & $1 \mathrm{~g} / \mathrm{l}$ & $2.5 \mathrm{~g} / \mathrm{l}$ & $5 \mathrm{~g} / \mathrm{l}$ \\
\hline Pino & $42^{\circ} 53.1$ & $09^{\circ} 17.7$ & 5.60 & 4.00 & 3.00 & 3.60 & 2.40 \\
St florent & $42^{\circ} 42.6$ & $09^{\circ} 17.2$ & 0.80 & 0.80 & 0.80 & 2.60 & 7.60 \\
Calvi & $42^{\circ} 35.1$ & $08^{\circ} 45.2$ & 6.00 & 0.80 & 4.80 & 5.80 & 2.40 \\
Sagone & $42^{\circ} 04.3$ & $08^{\circ} 42.5$ & 13.20 & 0.80 & 4.40 & 32.00 & 44.00 \\
Ajaccio north & $41^{\circ} 54.2$ & $08^{\circ} 41.7$ & 13.20 & 0.00 & 1.40 & 0.00 & 0.60 \\
Ajaccio south & $41^{\circ} 52.6$ & $08^{\circ} 45.9$ & 13.20 & 0.00 & 1.40 & 0.00 & 0.60 \\
Propriano & $41^{\circ} 41.5$ & $08^{\circ} 52.1$ & 12.80 & 0.00 & 0.60 & 4.60 & 5.00 \\
Figari & $41^{\circ} 26.8$ & $09^{\circ} 02.8$ & 12.80 & 0.00 & 2.80 & 2.00 & 2.30 \\
Sta Amanza & $41^{\circ} 26.7$ & $09^{\circ} 16.5$ & 8.80 & 1.00 & 2.20 & 2.40 & 0.20 \\
Cavu & $41^{\circ} 43.9$ & $09^{\circ} 24.9$ & 8.80 & 1.20 & 0.00 & 2.40 & 6.20 \\
Solenzara & $41^{\circ} 52.6$ & $09^{\circ} 26.4$ & 12.60 & 0.80 & 0.00 & 4.00 & 2.00 \\
Fiumorbu & $41^{\circ} 57.3$ & $09^{\circ} 29.4$ & 12.60 & 3.00 & 3.00 & 8.40 & 3.60 \\
Bastia sud & $42^{\circ} 38.6$ & $09^{\circ} 30.1$ & 16.80 & 5.60 & 7.20 & 10.40 & 12.00 \\
Porticciolo & $42^{\circ} 55.0$ & $09^{\circ} 29.9$ & 5.60 & 4.40 & 2.80 & 2.40 & 3.60 \\
& & & & & & & \\
\hline
\end{tabular}

